\title{
Exhaust emissions of non-road mobile machine : Real-world and laboratory studies with diesel and HVO fuels
}

\section{Pirjola, L.}

\section{7-08-15}

Pirjola , L , Rönkkö , T , Saukko , E , Parviainen , H , Malinen , A , Alanen , J \& Saveljeff , H 2017 , ' Exhaust emissions of non-road mobile machine : Real-world and laboratory studies with diesel and HVO fuels ' , Fuel , vol. 202 , pp. 154-164 . https://doi.org/10.1016/j.fuel.2017.04.029

http://hdl.handle.net/10138/300874

https://doi.org/10.1016/j.fuel.2017.04.029

cc_by_nc_nd

acceptedVersion

Downloaded from Helda, University of Helsinki institutional repository.

This is an electronic reprint of the original article.

This reprint may differ from the original in pagination and typographic detail.

Please cite the original version. 
1 Exhaust emissions of non-road mobile machine: real-world and 2 laboratory studies with diesel and HVO fuels

3

4 L. Pirjola ${ }^{a, b^{*}}$, T. Rönkköc , E. Saukkoc, H. Parviainen ${ }^{\mathrm{a}}$, A. Malinen ${ }^{\mathrm{a}}$, J. Alanen ${ }^{\mathrm{c}}$, H. Saveljeff ${ }^{\mathrm{d}}$

5 a Department of Technology, Metropolia University of Applied Sciences, P.O. Box 4021, FI-00180 Helsinki,

6 Finland

$7 \quad$ bepartment of Physics, University of Helsinki, P.O. Box 64, FI-00014 Helsinki, Finland

$8 \quad{ }^{c}$ Aerosol Physics Laboratory, Department of Physics, Tampere University of Technology, P.O. Box 692, FI-

933101 Tampere, Finland

10 d Turku University of Applied Sciences, Sepänkatu 1, 20700 Turku, Finland

11

12

*Corresponding author email: liisa.pirjola@metropolia.fi, liisa.pirjola@helsinki.fi

13

14

15

16

17 
18

\section{Abstract}

Exhaust emissions emitted by a non-road mobile machine were studied chasing a tractor in real-world conditions and repeating the same transient tests with a similar engine on an engine dynamometer where additionally, nonroad steady state tests were carried out. The engines were equipped with an oxidation catalyst (DOC) and a selective catalytic reduction (SCR) system, and they were fuelled by fossil diesel fuel with ultra-low sulphur content and hydrotreated vegetable oil (HVO). By substituting diesel fuel with HVO the on-road emissions of nitrogen oxides $\left(\mathrm{NO}_{\mathrm{x}}\right)$ reduced $20 \%$ and particle number $44 \%$, the emission factors being $\mathrm{EF}_{\mathrm{NOx}}=1.62 \pm 0.04 \mathrm{~g} / \mathrm{kWh}$ and $\mathrm{EF}_{\mathrm{N}}=(28.2 \pm 7.8) \times 10^{13} \# / \mathrm{kWh}$. Similar trend was observed for $\mathrm{NO}_{\mathrm{x}}$ at laboratory although the emissions were somewhat smaller than on-road. In contrast to real-world, in the laboratory experiment the $\mathrm{EF}_{\mathrm{N}}$ was only $2 \%$ smaller with HVO than with diesel, and these emission factors were almost one order of magnitude smaller than observed on-road. The number size distribution and volatility measurements showed that in real-world experiments small nucleation mode particles were formed during uphill and during downhill in engine braking conditions. These were not observed at laboratory. However, nucleation mode particles were observed in the laboratory experiments at high load steady driving conditions. At steady state tests the emissions strongly depended on engine load and engine speed with both fuels.

Keywords: real-world emissions, diesel engine, tractor, $\mathrm{HVO}$, exhaust emissions, particle size distribution, $\mathrm{NO}_{\mathrm{x}}$

\section{Highlights (3-5 bullet points)}

- exhaust emissions from a tractor in real-world and laboratory conditions were compared

- emission factors for $\mathrm{NO}_{\mathrm{x}}, \mathrm{PM}$, particles and non-volatile particles were determined

- HVO produced lower emissions compared to diesel

- emission factors were higher on-road compared to laboratory conditions

- highest particle emissions were observed on-road during accelerations and engine braking 


\section{Nomenclature}

ATS

after-treatment system

$\mathrm{CO}$ carbon monoxide

$\mathrm{CO}_{2} \quad$ carbon dioxide

CPC condensation particle counter

DOC diesel oxidation catalyst

DPF diesel particle filter

EC elemental carbon

ECU engine control unit

EEPS engine exhaust particle sizer

EGR exhaust gas recirculation

ELPI electrical low pressure impactor

EN590 standard diesel fuel

FAME fatty acid methyl ester
HC hydrocarbon

HVO hydrotreated vegetable oil

NEXBTL Neste renewable diesel fuel

NO nitrogen monoxide

$\mathrm{NO}_{\mathrm{x}} \quad$ nitrogen oxides

NRSC non-road steady cycle

PAH polycyclic aromatic hydrocarbon

PM particulate matter

PN particle number

SCR selective catalytic reduction

$\mathrm{SO}_{2} \quad$ sulphur dioxide

$\mathrm{SO}_{3} \quad$ sulphur trioxide

TD thermodenuder

\section{Introduction}

Non-road mobile machines powered by diesel engines, such as farm tractors, combines, excavators, cranes, and felling machines, are widely used in many different agricultural, construction and forest work. For example in Finland, considering all mobile on-road and non-road diesel engines in operation in 2014, the number of non-road machines constituted around 30\% of all of them, yet their emissions accounted for 49\%, 23\%, 59\%, 31\% and 42\% of yearly carbon monoxide $(\mathrm{CO})$, carbon dioxide $\left(\mathrm{CO}_{2}\right)$, hydrocarbon $(\mathrm{HC})$, nitrogen oxides $\left(\mathrm{NO}_{\mathrm{x}}\right)$, and particulate matter (PM) emissions, respectively [1]. Due to adverse health effects [2-6] and climate warming potential e.g. [7], the emissions of diesel vehicles are regulated. Since 1999, when the first emission standards (Stage 1) in the EU area for non-road mobile machinery were introduced, the particulate mass emissions of new engines have been reduced approximately $96 \%$ until 2014 when Stage IV was implemented [8]. The proposed Stage V emissions limits in 2019 will be more tightened, and also the particle number emission limit will be included in the standards. Furthermore, more attention should be paid to increasing combustion noise radiation from diesel engines as noise exposure is a potential risk for human health as well [54].

Particle number size distribution of diesel exhaust typically consists of two modes. Soot mode particles in the size range of $40-200 \mathrm{~nm}$ are formed in combustion processes [9]. They are composed of non-volatile carbonaceous 
soot agglomerates, onto which semi-volatile vapours can condense [9-10]. Nucleation mode particles $(<30 \mathrm{~nm})$, formed in the atmosphere during rapid cooling and dilution of emissions, consist of volatile material such as water, sulphate and hydrocarbons [9]. With some vehicle technologies and in some driving conditions, also small particles possessing non-volatile cores around $10 \mathrm{~nm}$ or less in size have been observed [11-14]. These particles are suggested to be formed by fuel aliphatic hydrocarbons [14] or lubricant oil metal compounds [15-16] coated by condensing volatile hydrocarbon and sulphur compounds $[12,16]$.

Diesel exhaust emissions, including the amount and the existence of different types of particles, significantly depend on engine parameters, exhaust after-treatment technology [17-19], fuel and lubricant oil properties [20$22,15]$ as well as driving and environmental conditions [15,23]. For example, Euro VI level on-road diesel vehicles are typically equipped with diesel particle filters (DPF) which remove almost all soot particles. The oxidative aftertreatment systems (ATS), such as diesel oxidation catalysts (DOCs), reduce exhaust hydrocarbon and carbon monoxide concentrations but simultaneously increase $\mathrm{SO}_{2}$ to $\mathrm{SO}_{3}$ conversion enhancing gaseous sulphuric acid formation $[24-25,20]$. The sulphuric acid has been shown to participate in condensation and nucleation processes during the dilution and cooling of the exhaust [24-28,10]. Selective catalytic reduction (SCR) or exhaust gas recirculation (EGR) systems have been used to reduce $\mathrm{NO}_{x}$ emissions [29].

Recently alternative fuels, such as biodiesel, ethanol, vegetable oils, and their blends with diesel fuel, have been developed and used in diesel engines. Only limited number of studies in the literature concern non-road diesel engines. Biodiesel is produced from vegetable oil (rape seed oil in Europe) by esterification. The products are called fatty acid methyl esters (FAME). The laboratory measurements have shown that $\mathrm{CO}, \mathrm{HC}, \mathrm{PM}$ and particle number (PN) emissions reduced while $\mathrm{NO}_{\mathrm{x}}$ emissions increased when $\sim 100 \mathrm{~kW}$ tractors were operating with biodiesel compared to diesel fuel [30-31]. Polycyclic aromatic hydrocarbon (PAH) emissions decreased as well [32]. Similar results were obtained for small non-road engine generators (4-7 kW), for example by [33], however, they report that at $80 \%$ engine load $\mathrm{NO}_{\mathrm{x}}$ emissions for biodiesel and biodiesel blends were lower in relation to conventional diesel. Tang et al. [34] discovered that $\mathrm{PM}_{2.5}$, $\mathrm{PN}$ and EC emissions increased with increasing engine load. Chung et al. [35] studied differences in the morphology of biodiesel and diesel particles, and discovered that for biodiesel the emitted particles were compact aggregates with irregular shapes, and primary particles were not clearly distinguishable. Additionally, Zhang et al. [36] used butanol-diesel blends, and discovered that the blends decreased PN, PM and EC emissions while PAH emissions and OC/EC ratio increased. At low engine load, 15\% and $20 \%$ butanol blends increased the number concentration of particles smaller than $15 \mathrm{~nm}$. Heikkilä et al. [37] report that by using FAME the emissions of soot particle number reduced but the emissions of sub-10 nm particles significantly increased. Recently, Rakopoulos et al. [55] compared the properties and emissions of conventional 
105

106

107

108

109

110

111

112

113

114

115

116

117

118

119

120

121

122

123

124

125

126

127

128

129

\section{0}

131

132

133

134

diesel fuel and its blends with vegetable cottonseed oil, biodiesel, ethanol and butanol. The results showed that the unburned HC emissions were higher, whereas the soot emissions were markedly lower by all the diesel fuel blends compared to neat diesel fuel. This trend increased as the fuel-bound oxygen content increased. The $\mathrm{NO}_{\mathrm{x}}$ emissions somewhat decreased for ethanol and butanol diesel fuel blends compared to diesel fuel, but trade-off between the soot and $\mathrm{NO}_{\mathrm{x}}$ emissions, typical for diesel fuel, was also observed for vegetable and biodiesel blends [55-56].

Hydrotreated vegetable oil (HVO) is a renewable diesel fuel whose feedstocks are vegetable oils (rapeseed, sunflower, soyben, palm, jatropha and algae oils) and waste animal fats. In the production process, hydrogen is used to remove the oxygen from the vegetable oil after which catalytic isomerization into branched alkanes is done to get paraffinic hydrocarbons. HVO offers some advantages compared to FAME, including higher cetane number, better storage stability, less cold operability and deposit problems [38]. By using HVO in Euro IV heavy duty vehicles with different ATS, the emissions of regulated components $\mathrm{NO}_{x}, \mathrm{PM}, \mathrm{CO}$ and $\mathrm{HC}$ reduced by 7-14\%, 28$46 \%, 5-78 \%$ and $0-48 \%$, respectively, compared to fossil diesel [38-39]. As well, compared to fossil fuel, HVO has been observed to reduce soot particle number emissions $[38,40]$, sulphuric acid emissions and subsequent nucleation mode particle emissions [25].

In this work gaseous emissions as well as particle number emissions and particle size distribution were measured from a tractor's exhaust plume. The test vehicle was fuelled by fossil diesel and HVO during transient driving. The measurements were made by a chasing method so that the mobile laboratory van "Sniffer" was installed on a trailer pulled by the tractor. Such special mobile research van technique has not previously been applied for studying non-road vehicle emissions. Transient tests were repeated at engine dynamometer with similar engine than used in the tractor and, additionally, the non-road steady cycle (NRSC) was measured. The study was designed to evaluate: 1) differences in $\mathrm{NO}_{\mathrm{x}}$ and particle emissions when the tractor was fuelled with regular EN590 diesel fuel and hydrotreated vegetable oil NEXBTL, 2) how well the emissions measured at laboratory compare with real-world emissions, and 3) emission factors over transient and steady state driving conditions in real-world and at laboratory.

\section{Experimental section}

\subsection{On-road measurements}

A non-road vehicle used in these tests was an agriculture tractor with maximum speed of $40 \mathrm{~km} / \mathrm{h}$. The tractor had a four cylinder $99 \mathrm{~kW}$ turbocharged, intercooled off-road diesel engine (Agco Power 44 AWI, displacement 4.4 L), meeting the European Stage 3B emission standard. It was equipped with a 4-valve cylinder head and a 
135

136

137

138

139

140

141

142

143

144

145

146

147

148

149

150

151

152

153

154

155

156

157

158

159

common rail injection system which can produce up to 1600 bar injection pressure. The main specification of the engine is given in Table 1.

Table 1. Test engine specification.

\begin{tabular}{|l|l|}
\hline Manufacturer & AGCO Power \\
\hline Stroke & $120 \mathrm{~mm}$ \\
\hline Bore & $108 \mathrm{~mm}$ \\
\hline Cylinder number & 4 \\
\hline Swept volume & $4.4 \mathrm{dm}^{3}$ \\
\hline Compression ratio & $17.4: 1$ \\
\hline Number of valves & $2+2$ \\
\hline Rated power & $100 \mathrm{~kW}$ at $2100 \mathrm{rpm}$ \\
\hline Max torque & $560 \mathrm{Nm}$ at $1500 \mathrm{rpm}$ \\
\hline Injection system & Common rail \\
\hline Turbocharger & 1 -stage waste-gate \\
\hline
\end{tabular}

To reduce $\mathrm{NO}_{\mathrm{x}}$ emission the vehicle was equipped with on oxidation catalyst and a selective catalytic reduction system (DOC+SCR). A commercial standard diesel fuel (EN590) with ultra-low sulphur content $(<10 \mathrm{mg} \mathrm{S} / \mathrm{kg}$ fuel) and a hydrotreated vegetable oil (NEXBTL, Neste Oil) were used. The fuel properties are given in Supplementary Table S1. Emissions of the tractor were measured on 12-13 August 2013 on a common low traffic asphalt road, when the tractor drove around $10 \mathrm{~km}$ northeast (direction 1), turned around and drove back to the starting point (direction 2), at Suolahti, Finland. The route included both uphill and downhill driving (Fig. 1a), and the route was repeated three times. Before the test route the tractor was driven for 20-30 minutes to warm the engine and consequently activate the SCR catalyst. The engine load changed substantially but the vehicle speed and engine speed were kept constant, approximately $40 \mathrm{~km} / \mathrm{h}$ and $1900 \mathrm{rpm}$, respectively (Fig. 1a). These parameters were saved with one second time resolution by the engine control unit (ECU). A mobile laboratory van "Sniffer" $[41,22,19]$ was installed on a trailer pulled by the tractor (Supplementary Fig. S1). The sampling height was $2.4 \mathrm{~m}$, at the same height as the exhaust pipe of the tractor. During the chasing experiments the ambient temperature was rather constant $16.0 \pm 1.8^{\circ} \mathrm{C}$ and relative humidity $75.3 \pm 10.2 \%$.

\subsection{Laboratory measurements}

A part of the transient test cycle measured at Suolahti (Fig. 1a) was repeated on the engine dynamometer (Schenk WT 400 eddy-current dynamometer) utilizing the ECU data saved during the on-road study. The test engine (Agco Power 44 AWI, $99 \mathrm{~kW}$ ) was of the same model but not the same individual as used with the tractor. The after-treatment system (DOC+SCR) with urea injection was also similar but not the same individual as used on-road. Both engines and ATS systems were provided by the manufacturer. Besides the transient tests, the measurements were performed over the non-road steady cycle (NRSC) which belongs to the ISO 8178-C1 
160

161

162

163

164

165

166

167

168

169
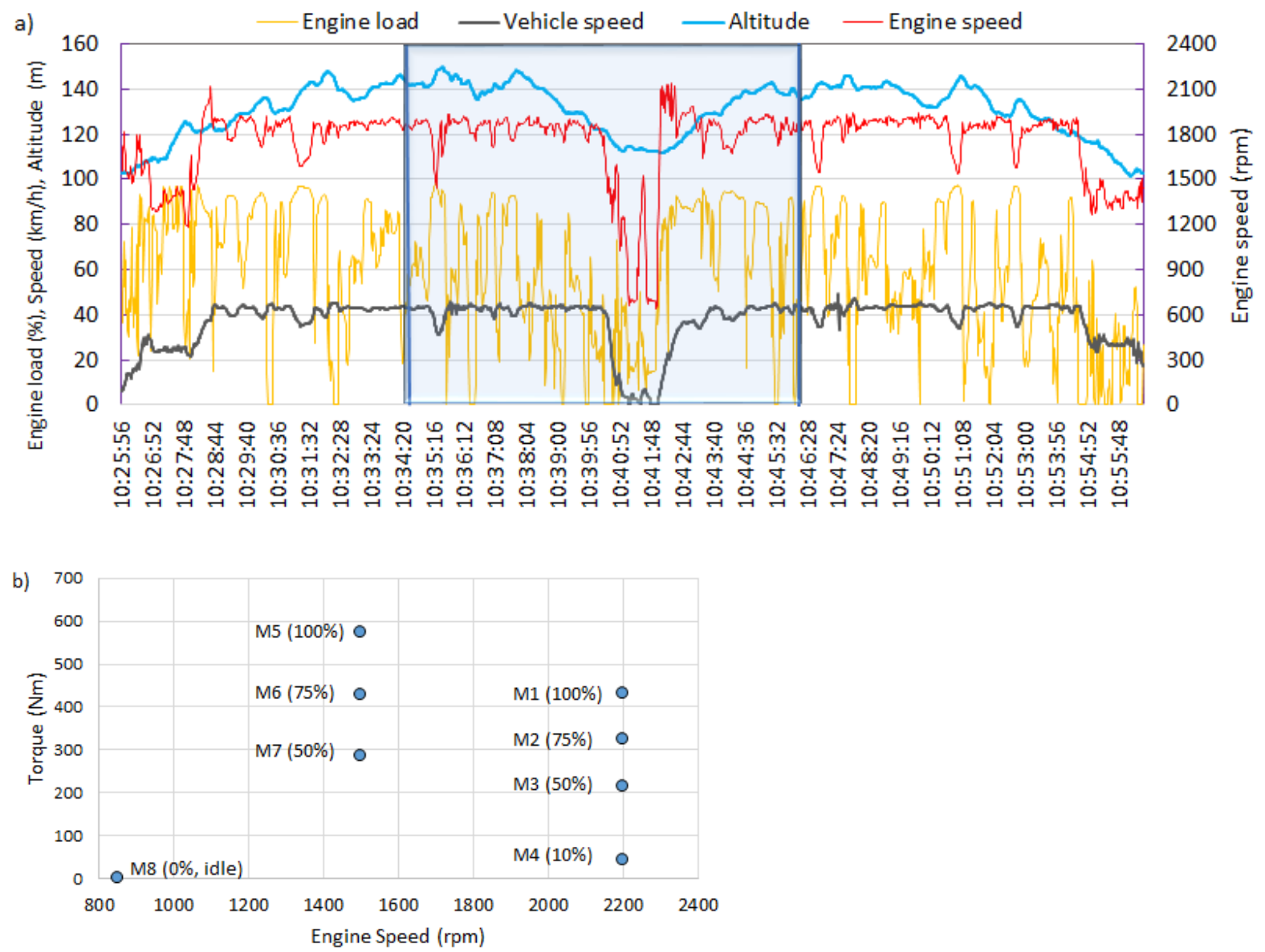

170

171 Figure 1.a) Transient cycle, $10 \mathrm{~km}$ to NE, turnaround, and $10 \mathrm{~km}$ back to SW. The shadowed part of the cycle was

172 repeated on the engine dynamometer. b) NRSC test points M1-M4 at $2200 \mathrm{rpm}$, M5-M7 at $1500 \mathrm{rpm}$, and idle at $173850 \mathrm{rpm}$.

174

175

standard. The NRSC includes 8 modes (M1-M8), four of them are performed at $2200 \mathrm{rpm}$ (nominal speed), three of them at 1500 PRM (intermediate speed), and one at idle (Fig. 1b).

After warming the engine ( $\sim 30$ minutes), the transient cycle was repeated seven times. After the transient cycles each mode of the standardized NRSC was stabilized for approximately 5-10 minutes and then measured for 5 minutes. This set-up was repeated for both fuels from the same batches as the ones used in on-road tests. Due to the limited amount of the fuels, the NRSC tests could be performed only once. The engine parameters and gaseous emissions (Supplementary Fig. S1b) were saved real-time $(\sim 0.1 \mathrm{~Hz})$ during the transient tests and with one minute time resolution during the steady tests.

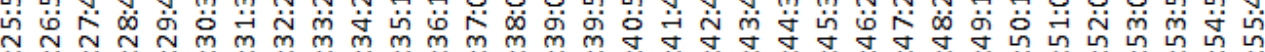

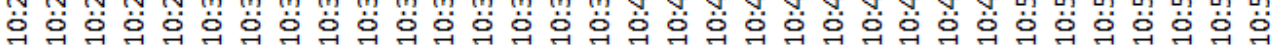

\subsection{Exhaust sampling and instrumentation}


The instrumentation in Sniffer is described in Supplementary Fig. S1a. Real-time $(1 \mathrm{~Hz})$ particle number size distribution was measured with an EEPS (engine exhaust particle sizer, model 3090, TSI Inc.), and with two ELPIs (electrical low pressure impactor, Dekati Ltd.). In the EEPS [42-43] particles are classified according to their mobility diameter, whereas the ELPIs [44] classify particles according to their aerodynamic diameter. The EEPS measurement covers the size range from 5.6-560 nm, whereas the ELPI measurements cover size ranges from 7 $\mathrm{nm}$ to10 $\mu \mathrm{m}$. In this study the ELPI was equipped with a filter stage [45] and an additional stage [46], both designed to enhance the particle size resolution for nanoparticles. The accuracy of particle size distribution measurement depends both on the accuracy of particle sizing and particle concentration measurements. It can be estimated that the most typical instruments were capable of measuring particle number emissions to within $\pm 15 \%$ across an emission range of four orders of magnitude [57]. However, the accuracy can be slightly lower in particle sizes near the lower size limits of instruments. The morphology of particles as well as the time resolution of instruments can also affect the accuracy of final results [58].

To investigate volatility properties of particles, the ELPI1 was used before and the ELPI2 after the treatment of the aerosol sample with a thermodenuder (TD) [47]. In the thermodenuder, the sample was first heated to 265 ${ }^{\circ} \mathrm{C}$, and after that led into the denuder where the cooled inner wall was covered with activated carbon to collect evaporated compounds. Particle losses in the TD were corrected according to [48]. Furthermore, the number concentration of particles larger than $2.5 \mathrm{~nm}$ was measured with one second time resolution by two ultrafine condensation particle counters (CPC model 3776, TSI), so that CPC1 was installed before and CPC2 after the TD.

194 The concentration accuracy by the CPC is $\pm 10 \%$.

195 Concentrations of gaseous $\mathrm{CO}_{2}$ (SickMaihak, SIDOR), $\mathrm{CO}$ (model CO12M, Environnement S.A.), and 196 nitrogen oxides $\mathrm{NO}, \mathrm{NO}_{2}$ and $\mathrm{NO}_{\mathrm{x}}$ (model APNA 360, Horiba) were monitored with a time resolution of $1 \mathrm{~s}$. The measurement range of $\mathrm{NO}_{\mathrm{x}}$ analyzer is from $0.5 \mathrm{ppb}$ to $1 \mathrm{ppm}$ with zero drift of $1 \mathrm{ppb} /$ day or $\pm 1 \%$ F.S. A weather station on the roof of the van at a height of $2.9 \mathrm{~m}$ above the ground level provided meteorological parameters.

The experimental setup at the laboratory (Supplementary Fig. S1b) was rather similar than presented by 200 Nousiainen et al [59]. For this study, the undiluted exhaust was measured after the ATS (hereafter called raw exhaust) with a Pegasor Particle Sensor (PPS), a smoke sensor (AVL 415 S), and a NOx sensor (Continental UNINOx) (Supplementary Table S2, Fig. S1). The accuracy was estimated to be $\pm(10-15) \%$ and $\pm(2-3) \%$ for the particulate mass and NOx, respectively. The gaseous emissions of $\mathrm{O}_{2}, \mathrm{CO}, \mathrm{CO}_{2}, \mathrm{HC}, \mathrm{NO}$ and $\mathrm{NO}_{\mathrm{x}}$ were measured 204 before the ATS (Fig. S1b), but they are not considered in this study apart from the raw exhaust $\mathrm{CO}_{2}$ (Servomex Xentra 4900) measurements. The PM emission factors were calculated based on the AVL smoke sensor. With 
207

$$
\frac{\Delta X}{\Delta C O_{2}}=\frac{\left(X-X_{b g}\right)}{\left(C O_{2}-C O_{2, b g}\right)}
$$

but from the diluted exhaust with two CPCs, two ELPIs and an EEPS, the same instruments as used during the onroad experiments. Exhaust dilution was conducted using a partial exhaust flow dilution system [49] consisting of a porous tube diluter with a dilution ratio of about 12, a short ageing chamber with a residence time of $2.6 \mathrm{~s}$, and a secondary diluter (a modified Dekati diluter) with a dilution ratio of about 8 (Supplementary Fig. S1b). Dilution air was filtered from particles. Both the primary dilution ratio and the total dilution ratio were calculated based on the $\mathrm{CO}_{2}$ concentration measured in the raw and diluted exhaust samples (Fig. S1b). The diluted $\mathrm{CO}_{2}$ concentration was measured by the same analyzer as used on road. Furthermore, an additional ejector diluter was needed before the CPCs. The sample reached a temperature of about $25^{\circ} \mathrm{C}$ after secondary dilution. This dilution system is considered to fairly well mimic the cooling and dilution processes encountered during real-world driving, especially in regard to exhaust nucleation particle formation $[23,50]$.

\subsection{Data analysis}

All instruments were synchronized before the start of the measurements, and comparison between the two CPCs and two ELPIs were done at least once per day. Data was adjusted accordingly. In order to eliminate differences in dilution conditions at Suolahti, background concentrations $X_{b g}$ and $\mathrm{CO}_{2, b g}$ for species $\mathrm{X}$ and carbon dioxide, respectively, were subtracted second by second, and normalized concentrations

were calculated. For the part of the cycle repeated at the laboratory, the raw exhaust concentrations on-road were calculated by multiplying the results from eq. (1) by momentary raw exhaust $\mathrm{CO}_{2}$ concentration measured at the 226 laboratory tests,

$$
X_{\text {raw }}=\frac{\Delta X}{\Delta C \mathrm{O}_{2}}\left(\mathrm{CO}_{2}^{\text {raw }}-\mathrm{CO}_{2, b g}^{\text {raw }}\right)
$$

228 Raw exhaust concentrations were then averaged over the three repetitions. At the laboratory, the measured particle number concentrations were multiplied by the momentary dilution ratio, obtained from the raw and diluted $\mathrm{CO}_{2}$ concentrations.

231 For transient cycle the emissions factors $\mathrm{EF}_{\mathrm{X}}$ for species $\mathrm{X}$ in $\# / \mathrm{kWh}$ for particle number and $\mathrm{g} / \mathrm{kWh}$ for gases, 232 were calculated by

$$
E F_{X}=\frac{\sum_{i=1}^{n} X_{\text {raw }, i} M F_{i}}{\rho_{\text {exh }} \sum_{i=1}^{n} P_{i}} A
$$


234 where $\mathrm{n}$ is the number of seconds, $\mathrm{MF}_{\mathrm{i}}$ is the momentary total mass flow (sum of air and fuel mass flows), $\rho_{\mathrm{exh}}$ is

235 the exhaust density (assumed to be air density), $\mathrm{P}_{\mathrm{i}}$ is the engine power per second and $\mathrm{A}$ is a conversion factor for 236 the units.

237 The specific emission factors $\mathrm{EF}_{\mathrm{X}}$ over the NRSC cycle $(\mathrm{g} / \mathrm{kWh})$ were calculated by

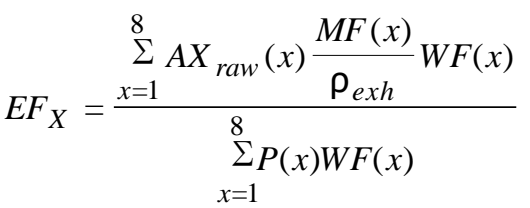

where the concentration $\mathrm{X}_{\text {raw }}$ of mode $\mathrm{x}$ is concerted to $\mathrm{g} / \mathrm{m}^{3}$ with a conversion factor $\mathrm{A}$, mass flow $\mathrm{MF}(\mathrm{x})$ to volume flow $\left(\mathrm{m}^{3} / \mathrm{s}\right)$ by dividing by the exhaust density, and $\mathrm{WF}(\mathrm{x})$ are weighting factors for the modes.

\section{3. Results and discussion}

\section{3.1. Particle number concentration during the on-road cycle}

244 As an example, Fig. 2a,c presents the normalized concentrations of particles larger than $2.5 \mathrm{~nm}$ and $7 \mathrm{~nm}$, measured with the CPC and ELPI, respectively, as a function of distance to direction 1 and Fig. 2b,d to direction

2462 of the on-road test route (Fig. 1a) for both fuels. The particle concentrations strongly depended on driving conditions, and the peak concentrations occurred when the tractor accelerated uphill or drove downhill. The repeatability of the data between the three rounds was very good with both fuels. In fact, the highest concentration peaks were observed during downhill driving when the torque was zero demonstrating that engine braking was used. However, it should be kept in mind that during downhill driving the concentrations of exhaust $\mathrm{CO}_{2}$ decreases substantially which, in principle, increases the relative role of simultaneous particle emissions. Typically, the concentrations with the regular diesel fuel were somewhat higher compared to HVO, even though the maximum value at a $3850 \mathrm{~m}$ distance from the start was $4.18 \times 10^{4} \mathrm{~cm}^{-3} \mathrm{ppm}^{-1}$ with diesel and $4.99 \times 10^{4} \mathrm{~cm}^{-3} \mathrm{ppm}^{-1}$ with HVO.

254 When driving uphill with high engine load, for example 1-2 km and 4-5 km from the start point, a major part of the formed particles with both fuels were highly volatile since after the TD most of them evaporated. In addition, these particles were smaller than $7 \mathrm{~nm}$ since the ELPI could not observe them until the end of the hill when a part of the particles had grown to larger sizes than $7 \mathrm{~nm}$. During downhill a smaller part of the particles evaporated and larger than $7 \mathrm{~nm}$. 

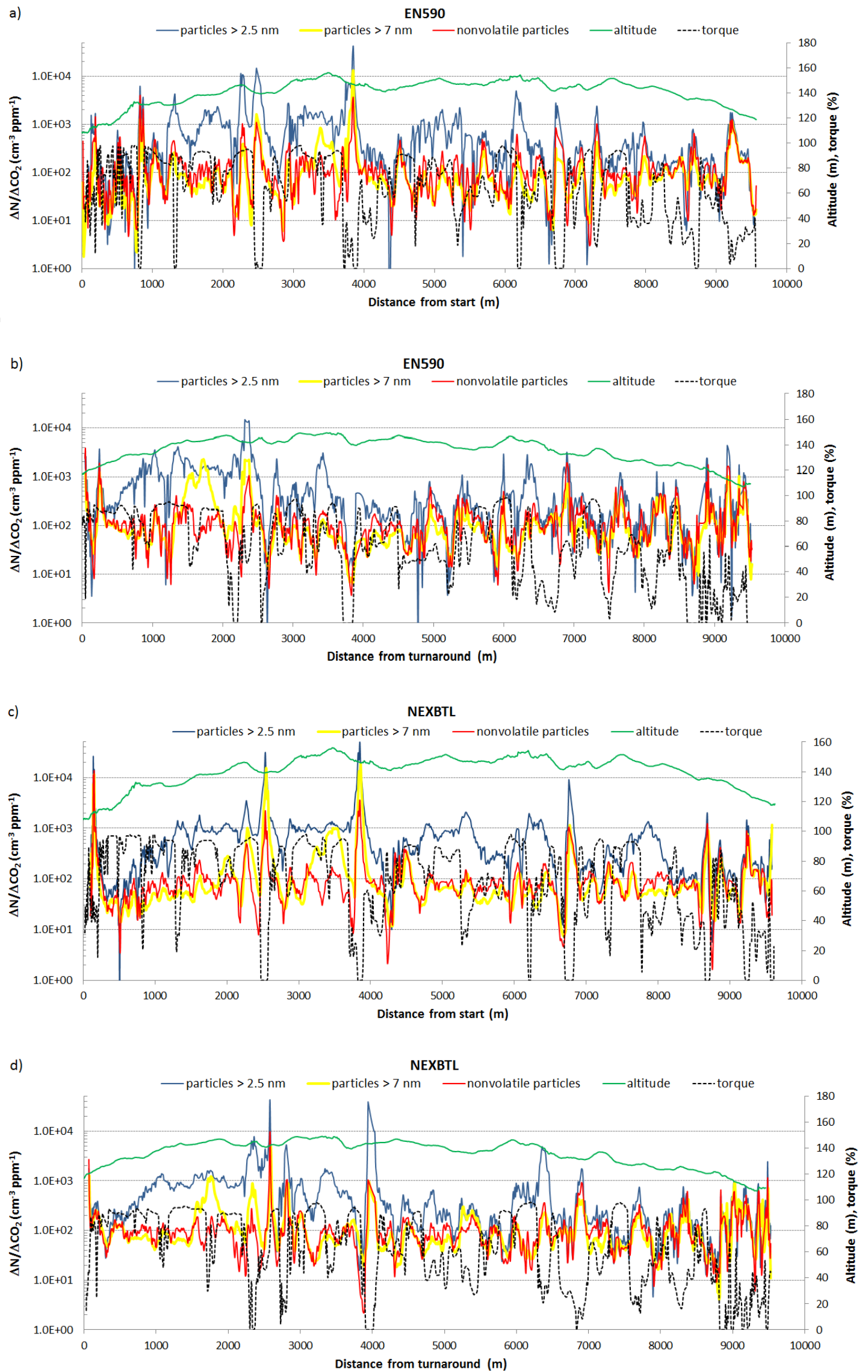

Figure 2. Time series of normalized particle number concentration, altitude and torque to direction 1 of the test cycle at Suolahti, when the tractor was fuelled with the regular diesel fuel (a)-(b), and with the hydrotreated 


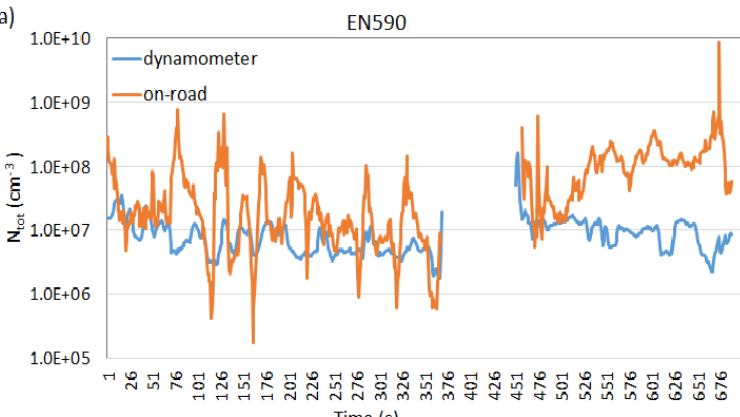

Time (s)

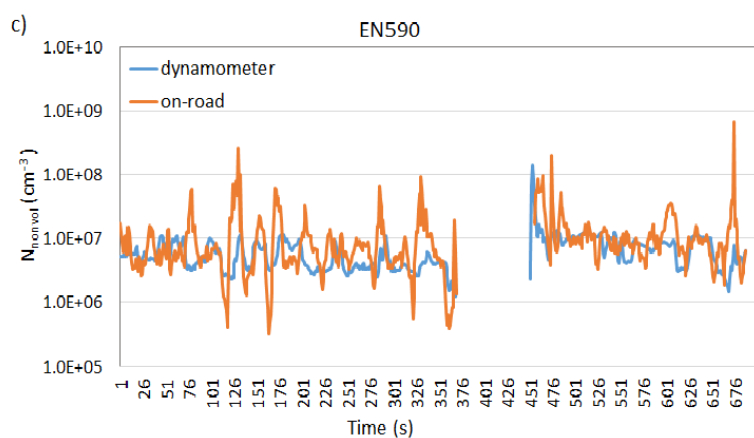

279

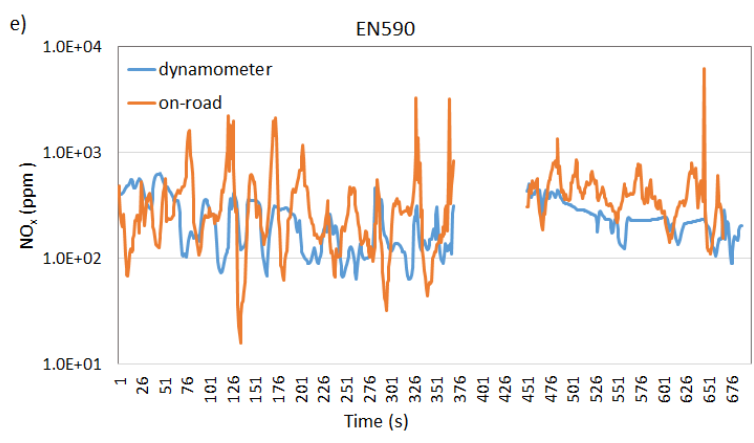

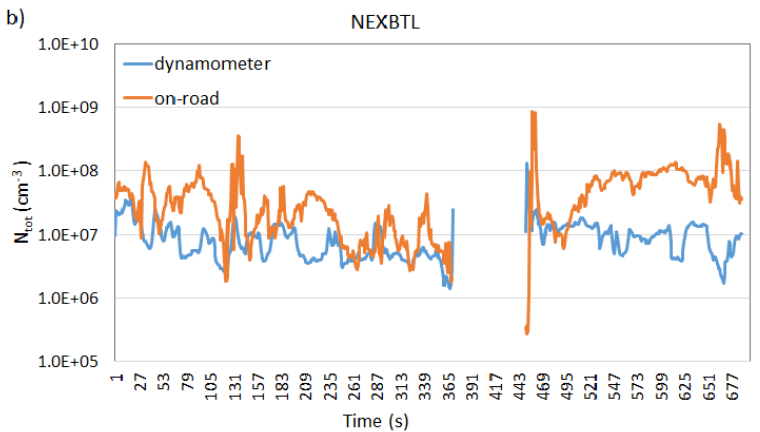
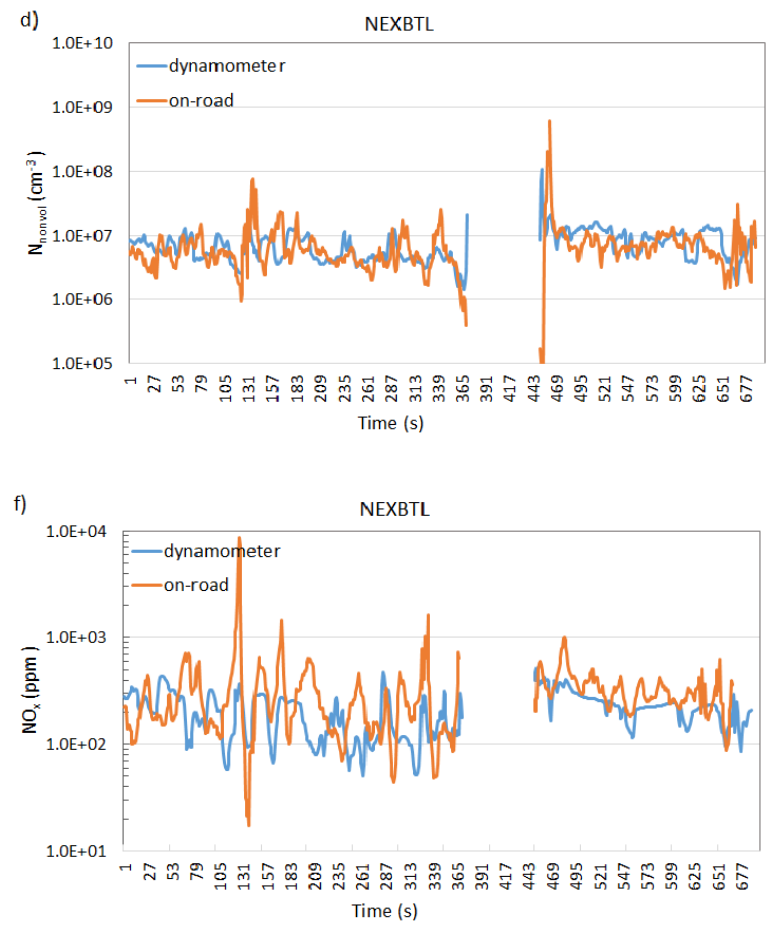

vegetable oil (c)-(d). The concentrations were measured with the CPC and ELPI before the TD, and with the other CPC after the TD.

\subsection{Comparison of the on-road and dynamometer tests}

Figure 3 presents the time series of the exhaust particle number and $\mathrm{NO}_{\mathrm{x}}$ concentrations over the part of the transient cycle repeated on road and on the dynamometer, separately for the both fuels used. The presented values represent raw exhaust concentrations, i.e. the measured values were corrected by dilution ratio of exhaust. The concentrations are the average values over the three repetitions, and the first 373 seconds refer to direction 1 , the next 80 seconds to turnaround and the rest 238 seconds to direction 2 (Fig. 1a). On road, a sudden growth of engine speed during the turnaround resulted in a high peak. Consequently, the data during the turnaround was excluded from both on road and dynamometer results. Emission factors for all and nonvolatile particles as well as for $\mathrm{NO}_{\mathrm{x}}$ over the cycle were calculated (Table 2, Supplementary Fig. S2). 
281 Figure 3. Comparison of the concentrations of particle number, nonvolatile particle number (after TD treatment), and nitrogen oxides over the same transient cycle on-road and on the dynamometer. Left side graphs represent the concentrations for diesel fuel and right side graphs for HVO fuel. The concentrations were measured by the CPCs and calculated to raw exhaust. The turnaround data was excluded.

Table 2. Emission factors over the transient cycle on-road and at the laboratory, excluding the turnaround data.

$\begin{array}{lllll} & \text { on-road } & \text { on-road } & \text { laboratory } & \text { laboratory } \\ & \text { EN590 } & \text { NEXBTL } & \text { EN590 } & \text { NEXBTL } \\ \mathrm{EF}_{\text {Ntot }}\left(\mathrm{x} 10^{13} \# / \mathrm{kWh}\right) & 50.4 \pm 13.1 & 28.2 \pm 7.8 & 6.03 \pm 0.49 & 5.92 \pm 0.60 \\ \mathrm{EF}_{\text {Nnonvol }}\left(\mathrm{x} 10^{13} \# / \mathrm{kWh}\right) & 7.48 \pm 1.44 & 4.87 \pm 0.12 & 4.23 \pm 0.26 & 4.79 \pm 0.26 \\ \mathrm{NO}_{\mathrm{x}}(\mathrm{g} / \mathrm{kWh}) & 2.03 \pm 0.24 & 1.62 \pm 0.04 & 1.33 \pm 0.15 & 1.09 \pm 0.01\end{array}$

When exploring the results in more detail some interesting features can be observed. First, the raw concentrations and emission factors of particles and $\mathrm{NO}_{\mathrm{x}}$ were higher on road than at the laboratory tests. However, the emission factors of the non-volatile soot particles were almost the same for NEXBTL in both environments. This is conspicuous especially to direction 2 during long uphill driving (Fig. 3). For the diesel fuel the $\mathrm{EF}_{\text {Ntot }}$ was 7.4 times higher in the real-world tests compared to the laboratory tests, and for the HVO 3.8 times higher, whereas the increment percent of $\mathrm{EF}_{\mathrm{NOx}}$ was around $50 \%$ for both fuels. Fuel affected the $\mathrm{NO}_{\mathrm{x}}$ emissions so that the emission factors with HVO were $\sim 20 \%$ lower than with diesel during both real-world and laboratory experiments.

Due to the lack of reported real-world emissions factors from tractors in the literature, we compare the $\mathrm{EF}_{\mathrm{Ntot}}$ and $\mathrm{EF}_{\mathrm{NOx}}$ with the results by Saari et al. [51] and Pirjola et al. [19]. Saari et al. chased by Sniffer a heavy duty diesel truck equipped with a SCR system and fuelled with standard diesel over its normal route in Finland, and obtained an average $\mathrm{EF}_{\mathrm{Ntot}}$ of around $1 \times 10^{15} \# / \mathrm{kg}$ fuel and $\mathrm{EF}_{\mathrm{NOx}}$ of around $3.55 \mathrm{~g} / \mathrm{kWh}$. Pirjola et al. chased by Sniffer city buses and report for the diesel fuelled buses with the SCRs an average $\mathrm{EF}_{\mathrm{Ntot}}$ of around $7 \times 10^{14} \# / \mathrm{kg}$ fuel, and $\mathrm{EF}_{\mathrm{NOx}}$ of around $40 \mathrm{~g} / \mathrm{kg}$ fuel indicating that the SCR was not working correctly. Since the reported particle number emission factors are given in \#/kg fuel, the on-road results of this study were additionally calculated in this unit by assuming the average $\mathrm{CO}_{2}$ emission factor of $3160 \mathrm{~g} / \mathrm{kg}$ fuel for diesel and $3120 \mathrm{~g} / \mathrm{kg}$ fuel for HVO [52]. This resulted in the values of $5.5 \times 10^{14} \# / \mathrm{kg}$ fuel and $1.0 \times 10^{15} \# / \mathrm{kg}$ fuel for diesel and HVO,

304 respectively, the same order of magnitude as in the published studies.

Although the tests were conducted at similar transient driving conditions on-road and laboratory, dilution 


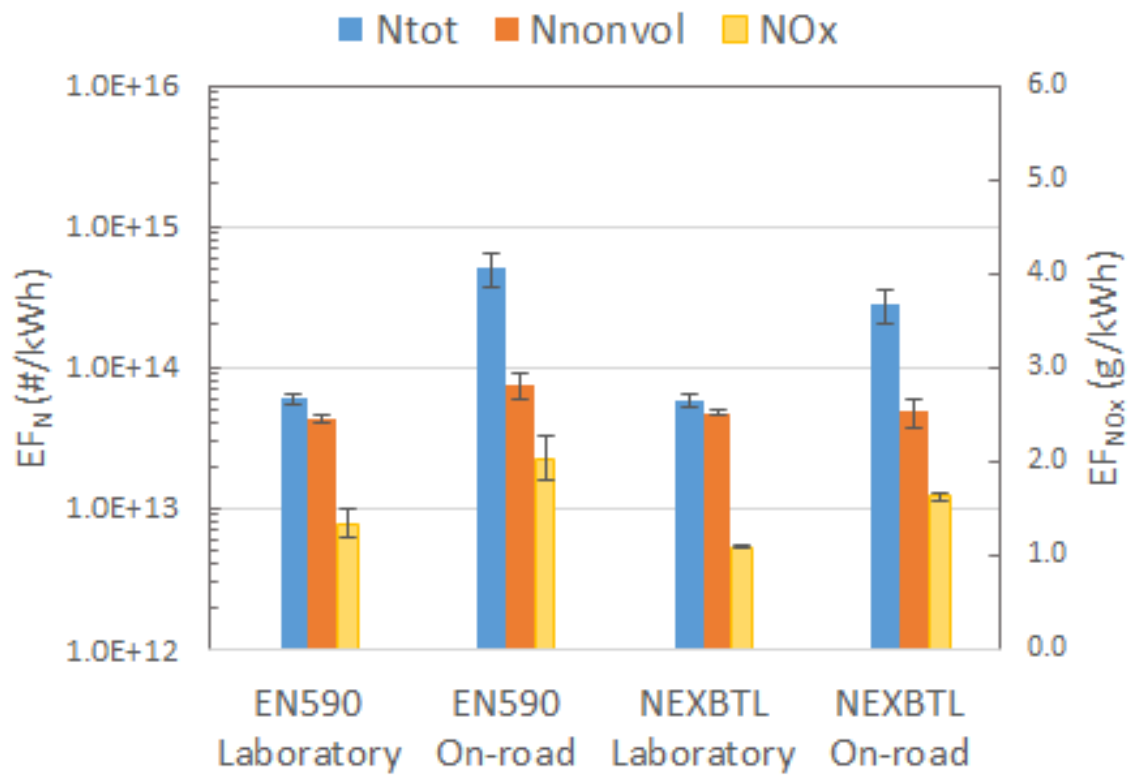

Figure S2. Emissions factors for total particle number, nonvolatile particle number and NOx over the transient cycle under realworld and laboratory conditions excluding turnaround. The engine was fuelled with standard diesel and with NEXBTL hydrotreated vegetable oil.
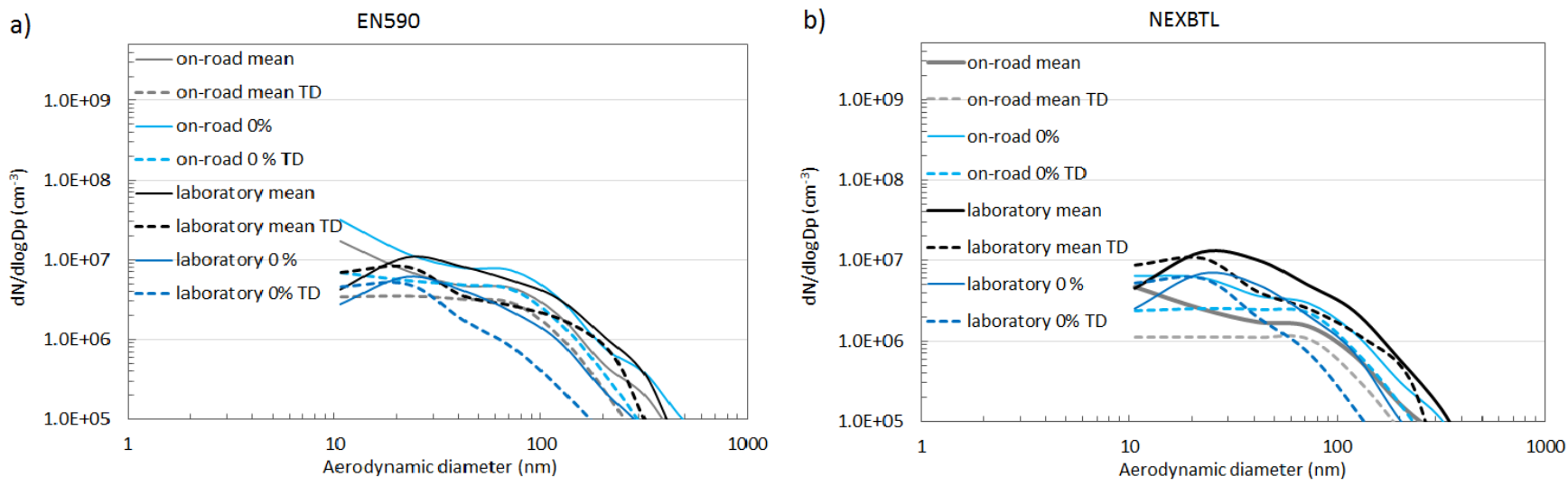

Figure S3. Mean particle number size distibutions during transient tests measured with the ELPIs, with and without the thermodenuder (TD). Measurements were made both in real-world and in laboratory conditions. 
nucleated particles is very sensitive to dilution ratio, temperature and relative humidity of the diluting air $[53,50]$, and these processes strongly affect particle number concentration and number size distribution.

$$
\text { Secondly, the fuel significantly affected the volatile particle emissions, but not much solid soot particles. The }
$$
emission factors of particle number were higher with the regular diesel fuel than with the HVO, in fact, $79 \%$ higher on-road but only $2 \%$ higher at the laboratory. The nonvolatile fraction of particles (by number) was 0.15 and 0.17 for EN590 and NEXBTL on-road, but 0.70 and 0.81 at the laboratory, respectively. This indicates that with both fuels volatile particle formation occurred on road but not in the laboratory although the engine, exhaust aftertreatment and fuels as well as the loading of engine were similar in both experiments.

$$
\text { Average particle number size distributions were calculated over the whole route (Fig. 4). The measurements }
$$
were carried out with the EEPS. At the laboratory conditions the size distributions were similar with both fuels, and the soot modes peaking at around $45 \mathrm{~nm}$ (mobility diameter) dominated the size distributions. Contrary to that, high nucleation modes peaking at $10 \mathrm{~nm}$ dominated under real-world conditions with both fuels, but stronger nucleation occurred with the diesel fuel. The soot mode was somewhat lower with the HVO than with the diesel. Regardless of that the modal mean diameters were the same, around $45 \mathrm{~nm}$, as also observed at the laboratory tests.

Additionally, the size distributions were calculated over all seconds with zero torque (Fig. 4) to study engine braking conditions. A notable nucleation mode was observed with both fuels, stronger with the diesel fuel, but also soot particles were present, and their concentration was even somewhat higher compared to the whole route averages. The source of these volatile nucleation mode particles is unclear, however, it should remember that driving history, and storage and release of semi-volatile compounds in the exhaust after-treatment can affect the results. In any case, our results disagree with the results by Rönkkö et al. [13] and Karjalainen et al. [53] who did not observe soot particles but observed non-volatile nucleation mode particles during engine braking under realworld conditions with a heavy duty diesel truck if it was equipped with an oxidative catalyst or no ATS was installed. The non-volatile nucleation mode particles were associated with lubricant oil consumption. However, Saari et al. [51] discovered that when a diesel truck was equipped with a SCR, a part of the nucleation mode particles were volatile as is the case in this study.

$$
\text { As seen from Fig. } 2 \text { the nucleation mode particles, formed uphill or downhill, were semi-volatile and a part of }
$$
them evaporated in the thermodenuder, independently of the used fuel. To investigate the volatility properties of the size distribution, two ELPIs, with and without the TD, were used. Unfortunately, due to very small sizes the nucleation mode particles could not be really well detected with the ELPI (Fig. S3). 
a)

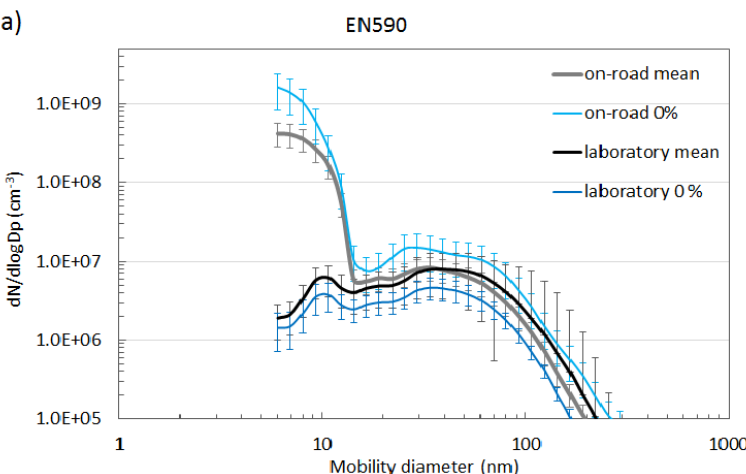

b)

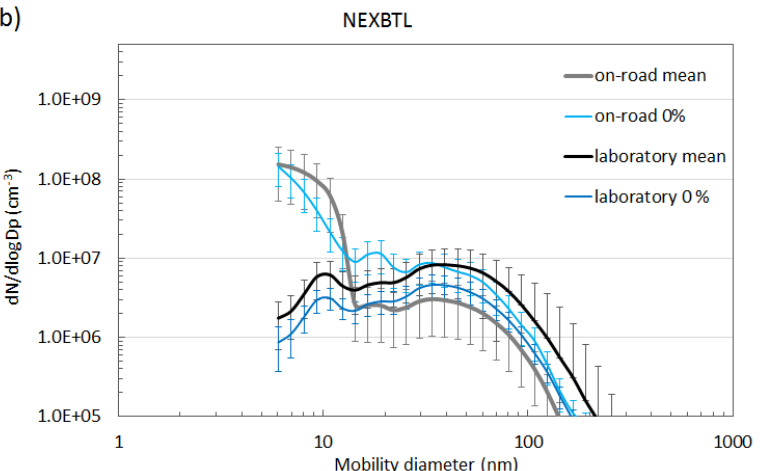

Figure 4. Comparison of average number size distributions on-road and at the laboratory with regular diesel (a) and hydrotreated vegetable oil (b). Averages with standard deviations were calculated over the whole route and under the conditions with zero torque. Concentrations were calculated to raw exhaust.

\subsection{Emissions over the ISO 8178 C1 cycles}

During the steady state ISO C1 cycles the particle number emissions factors, based on the CPC data, depended on engine speed, engine load and fuel. At $2200 \mathrm{rpm}$ the highest values for both fuels were obtained at low engine load while the smallest values were obtained at 50\% load after which the values slightly increased with increasing engine load (Fig. 5 and Table 3). EFs at idle cannot be defined as the power is zero. An increasing trend from 50\% to $100 \%$ engine load was also observed at $1500 \mathrm{rpm}$. Tang et al. [34] presented similar behaviour for particle number emission factor for a small non-road diesel generator. The $\mathrm{EF}_{\mathrm{N}}$ at idle was approximately two orders of magnitude higher than at 50\% engine load with both fuels. Similar behaviour was also observed for EFPM, and the use of HVO reduced the PM emissions up to $49 \%$ compared with the use of diesel. The emissions factors for $\mathrm{NO}_{\mathrm{x}}$ had similar trends as $\mathrm{EF}_{\mathrm{N}}$, yet they did not depend on fuel. Due to an artifact in $\mathrm{NO}_{\mathrm{x}}$ sensor with NEXBTL, the results are missing at modes M3, M4 and M7. To estimate if the emission standards were fulfilled by the engine, the emission factors for $\mathrm{NO}_{\mathrm{x}}$ and $\mathrm{PM}$ for diesel fuel were calculated over the NRSC according to eq. (4), The obtained values were $\mathrm{EF}_{\mathrm{NOx}}=2.1 \mathrm{~g} / \mathrm{kWh}$ and $\mathrm{EF}_{\mathrm{PM}}=0.0032 \mathrm{~g} / \mathrm{kWh}$, whereas the Stage III A/B emission standards are $3.3 \mathrm{~g} / \mathrm{kWh}$ for NOx and 0.025 g/kWh for PM for 75-130 kW non-road diesel engines 

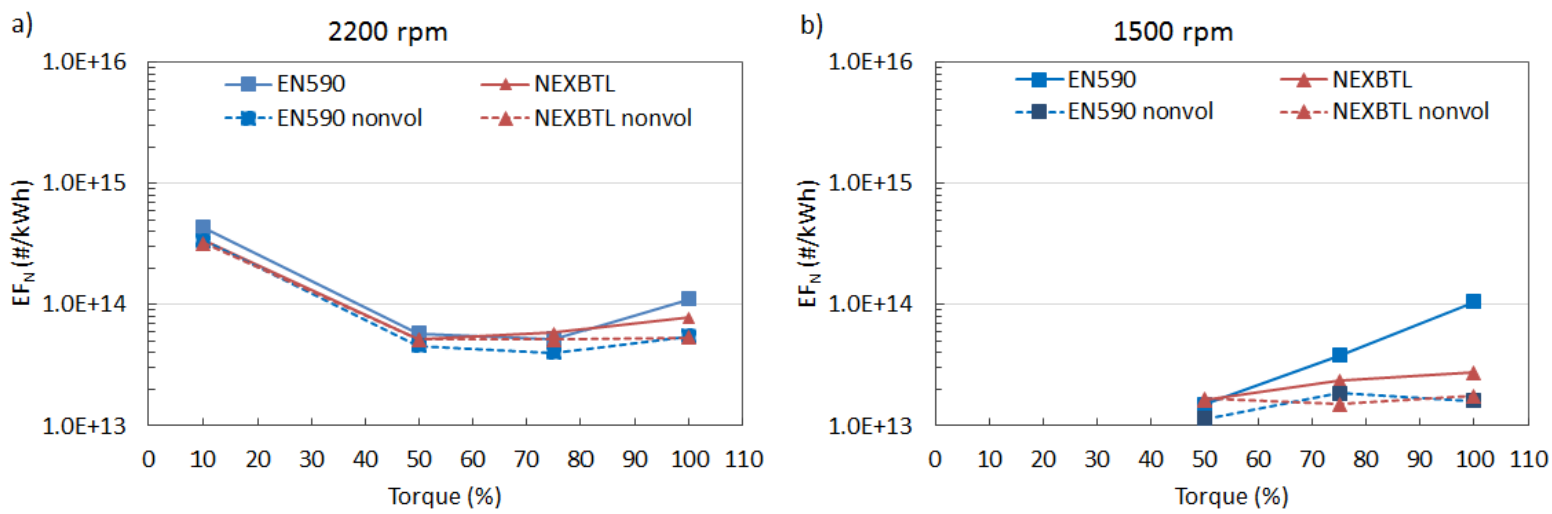

Figure 5. Emission factors for all particles and for nonvolatile particles during the steady state test modes M1-M4 at $2200 \mathrm{rpm} \mathrm{(a),} \mathrm{and} \mathrm{M5-M7} \mathrm{at} 1500 \mathrm{rpm}(\mathrm{b})$.

Table 3. Pointwise emission factors for all particles $(>2.5 \mathrm{~nm})$ and nonvolatile particles as well as for PM and

$\mathrm{NO}_{\mathrm{x}}$. Mode 8 is omitted as the emission factor for idle mode is not defined.

\begin{tabular}{|c|c|c|c|c|c|c|c|c|}
\hline & \multicolumn{4}{|c|}{ EN590 } & \multicolumn{4}{|c|}{ NEXBTL } \\
\hline Mode & $\begin{array}{c}\mathrm{EF}_{\mathrm{N}} \\
\mathrm{x} 10^{13} \\
\# / \mathrm{kWh}\end{array}$ & $\begin{array}{c}\mathrm{EF}_{\text {Nnonvol }} \\
\mathrm{x} 10^{13} \\
\# / \mathrm{kWh}\end{array}$ & $\begin{array}{c}\mathrm{PM} \\
\mathrm{mg} / \mathrm{kWh}\end{array}$ & $\begin{array}{l}\mathrm{EF}_{\mathrm{NOx}} \\
\mathrm{g} / \mathrm{kWh}\end{array}$ & $\begin{array}{c}\mathrm{EF}_{\mathrm{N}} \\
\mathrm{x} 10^{13} \\
\# / \mathrm{kWh}\end{array}$ & $\begin{array}{c}\mathrm{EF}_{\text {Nnonvol }} \\
\mathrm{x} 10^{13} \\
\# / \mathrm{kWh}\end{array}$ & $\begin{array}{c}\mathrm{PM} \\
\mathrm{mg} / \mathrm{kWh}\end{array}$ & $\begin{array}{l}\text { EF }_{\text {NOx }} \\
\text { g/kWh }\end{array}$ \\
\hline M1 & 11.1 & 5.5 & 4.1 & 2.4 & 7.9 & 5.4 & 3.6 & 2.3 \\
\hline $\mathrm{M} 2$ & 5.2 & 4.0 & 2.1 & 1.6 & 5.9 & 5.1 & 1.5 & 1.5 \\
\hline M3 & 5.8 & 4.6 & 3.2 & 2.9 & 5.2 & 5.1 & 2.0 & \\
\hline M4 & 43.3 & 33.6 & 29.7 & 11.2 & 33.7 & 32.2 & 15.1 & \\
\hline M5 & 10.6 & 1.6 & 2.9 & 1.6 & 2.7 & 1.8 & 2.4 & 1.6 \\
\hline M6 & 3.8 & 1.9 & 0.9 & 1.3 & 2.3 & 1.5 & 1.0 & 1.3 \\
\hline M7 & 1.5 & 1.1 & 1.2 & 1.4 & 1.6 & 1.7 & 1.0 & \\
\hline
\end{tabular}

Fig. 5 also displays the nonvolatile particle emissions factors $\left(\mathrm{EF}_{\mathrm{Nnonvol}}\right)$. At M1-M4 for both fuels, the fraction of volatile particles was rather constant, in average 0.22 for diesel and 0.06 for HVO, up to $75 \%$ engine load, but increased to 0.50 and 0.31 , respectively, at $100 \%$ engine load. Even a higher increase was observed at $1500 \mathrm{rpm}$ when the volatile particle fraction increased up to 0.85 and 0.36 for diesel and HVO, respectively. It turned out that during the steady modes M1 and M5 a lot of small particles were formed after 2-3 minutes from the start of the real measurement time (section 2.2). Supplementary Fig. S4 illustrates the time series of particle number

372 concentrations, measured by the CPC and EEPS without and by the other CPC with the TD, and converted to raw 373 exhaust. As observed, the nucleated particles were very small since they were not detected by the EEPS and, in 374 addition, their concentration changed strongly during the measurement. This kind of behavior in particle 
concentration has been linked in previous studies with the storage of sulphur compounds in the tailpipe system $[15,16,17,25,53]$, e.g. on the surfaces of catalytic converters.

In general, the particle size distributions for both fuels under all driving conditions possessed two modes, one peaking at around $10 \mathrm{~nm}$ and the other at around $40 \mathrm{~nm}$ (Fig. 6). The concentrations depended on the engine speed so that they were smaller at $1500 \mathrm{rpm}$ compared to $2200 \mathrm{rpm}$. Fuel had effects on the concentrations of the larger particles $(>50 \mathrm{~nm})$ which resulted in somewhat smaller particle sizes when the engine was fuelled with HVO. Besides, during idle a small increase in the nucleation particle concentration was observed, particularly with the diesel fuel. Yet, the soot mode concentrations were clearly smaller than at other driving conditions.
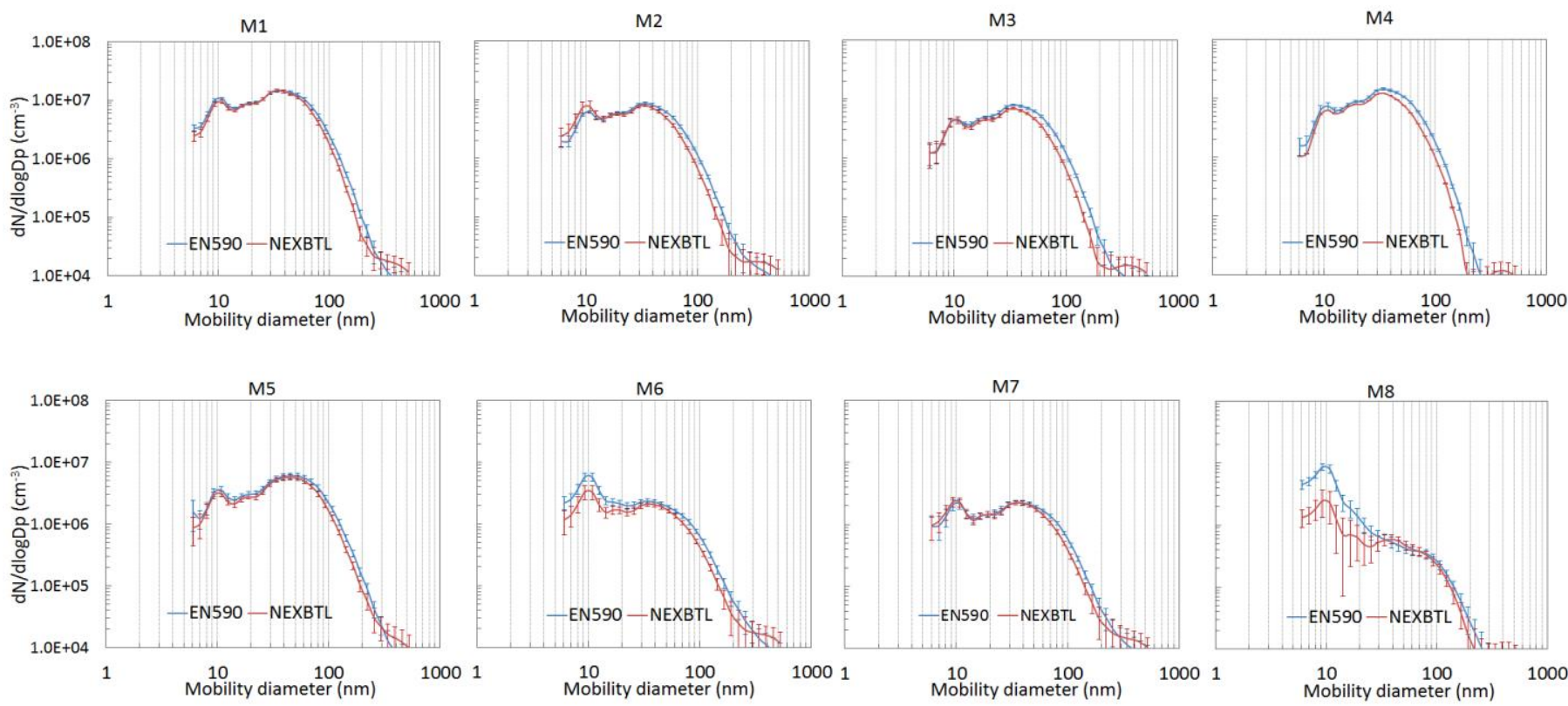

385 Fig. 6. Particle number size distributions over the steady modes M1-M8 with both fuels. The concentrations were measured by the EEPS and calculated to raw exhaust.

\section{Conclusions}

Mobile non-road diesel engine exhaust emissions were studied by chasing the tractor on-road with the mobile laboratory Sniffer and by repeating the same transient tests on the engine dynamometer, where additionally, the non-road steady state tests were carried out. The driving conditions were observed to significantly affect the emissions.

In general, the concentrations and emission factors with HVO were lower than with diesel fuel, yet, with both

394 fuels the peak concentrations of semi-volatile nucleation mode particles $(<7 \mathrm{~nm}$ in size $)$ were observed during real-world uphill and downhill driving. Only a small part of these particles could be observed at the laboratory conditions resulting in a big difference in particle number emission factor and size distributions compared with 
the on-road results. The number emission factor reduced $44 \%$ on-road and $2 \%$ at the laboratory when the fuel was changed from diesel to HVO. Simultaneously, the emission factor of nonvolatile soot particles reduced $35 \%$ onroad but increased $13 \%$ at the laboratory. On the other hand, the $\mathrm{EF}_{\mathrm{N}}$ with diesel was 7.4 and with HVO 3.7 times higher on-road compared to the dynamometer tests but in this comparison no significant difference was observed

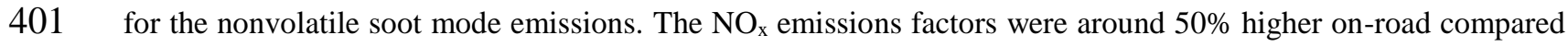
to the laboratory conditions, and in both cases $\mathrm{EF}_{\mathrm{NOx}}$ reduced by $\sim 20 \%$ when $\mathrm{HVO}$ was used.

The steady state ISO $8178 \mathrm{C} 1$ cycles also confirmed that the particle number and mass emissions with HVO were lower than with diesel, yet $\mathrm{NO}_{\mathrm{x}}$ emissions were rather similar with both fuels. The $\mathrm{EF}_{\mathrm{N}}$ varied in the range of $1.5 \times 10^{13}-2.4 \times 10^{15} \# / \mathrm{kWh}$ with diesel and $1.6 \times 10^{13}-6.6 \times 10^{14} \# / \mathrm{kWh}$ with HVO. The emissions depended on engine load and engine speed. The highest emissions were obtained at idle, lowest at the 50\% engine load, after which the emissions factors increased with increasing engine load. During all steady modes the number size distribution was bimodal, and the modes peaked at around $10 \mathrm{~nm}$ and $40 \mathrm{~nm}$ with both fuels. However, the soot mode particles larger than $50 \mathrm{~nm}$ in diameter were smaller with $\mathrm{HVO}$ compared with diesel resulting in smaller PM emissions with HVO.

At the laboratory the particles were measured after sampling exhaust by the system which has been observed to mimic real-world nanoparticle formation phenomenon. However, in this study very different nanoparticle results

413 were obtained for the transient cycle used in real-world and at laboratory, likely due to different nanoparticle formation in the real exhaust plume and in the laboratory sampling system. Especially the formation of volatile nucleation mode particles, e.g. via nucleation of sulphuric acid, is very sensitive on driving history of the vehicle or engine. For example, we observed that nanoparticles were formed at high load steady state conditions at the laboratory, and under these conditions the nanoparticle concentrations increased as a function of time. This indicates that the storage of nucleation mode particle precursors affected the nucleation mode particle concentrations, and might explain differences between laboratory and real-world experiments. In addition, the laboratory experiments did not fully mimic the engine breaking conditions when high nanoparticle concentrations were observed on-road.

\section{Acknowledgements}

424 This work was a part of the Concept Car project funded UPM Oyj, AGCO Power, Valtra, and the Finnish Funding Agency for Technology and Innovation (TEKES) (Contract no 40293/11). 


\section{References}

[1] LIPASTO-VTT, http://lipasto.vtt.fi/ 2014.

430 [2] Pope III CA, Dockery DW. Health effects of fine particulate air pollution: Lines that connect. J. Air Waste 431 Manage. Assoc. 2006; 56:707-742.

432 [3] Sioutas C, Delfino RJ, Singh M. Exposure assessment for atmospheric ultrafine particles (UFPs) and 433 implications in epidemiologic research. Environ. Health Perspect. 2005;113: 947-955.

434 [4] Kettunen J, Lanki T, Tiittanen P, Aalto PP, Koskentalo T, Kulmala M et al. Associations of fine and ultrafine 435 particulate air pollution with stroke mortality in an area of low air pollution levels. Stroke 2007;38: 918-922.

436 [5] Su DS, Serafino A, Müller JO, Jentoft RE, Schlögl R. Fiorito S. Cytotoxicity and Inflammatory Potential of 437 Soot Particles of Low-Emission Diesel Engines. Environ. Sci. Technol. 2008;42:1761-1765.

438 [6] Jacobs L, Nawrot TS, de Geus B, Meeusen R, Degraeuwe B, Bernard A et al. Subclinical responses in healthy 439 cyclists briefly exposed to traffic-related air pollution: an intervention study. Environ. Health 2010;9:64-71.

440 [7] Bond TC, Doherty SJ, Fahey DW, Forster PM, Berntsen T, DeAngelo BJ et al. Bounding the role of black 441 carbon in the climate system: A scientific assessment. J. Geophys. Res. Atmos. 2013;118: 5380-5552.

442 [8] DieselNet 2014. https://www.dieselnet.com/standards/eu/nonroad.php

443 [9] Kittelson DB. Engines and nanoparticles: A review. J. Aerosol Sci. 1998;29:575-588.

444 [10] Tobias H, Beving D, Ziemann P, Sakurai H, Zuk M, McMurry P et al. Chemical analysis of diesel engine 445 nanoparticles using a nano-DMA/thermal desorption particle beam mass spectrometer. Environ. Sci. Technol.

$446 \quad 2001 ; 35: 2233-2243$.

447 [11] Sakurai H, Tobias H, Park K, Zarling D, Docherty K, Kittelson D et al. On-line measurements of diesel 448 nanoparticle composition and volatility. Atmos. Environ. 2003;37: 1199-1210.

449 [12] Rönkkö T, Virtanen A, Kannosto J, Keskinen J, Lappi M et al. Nucleation mode particles with a non-volatile 450 core in the exhaust of a heavy duty diesel vehicle. Environ. Sci. Technol. 2007;41:6384-6389.

451 [13] Rönkkö T, Pirjola L, Ntziachristos L. Heikkilä J, Karjalainen P, Hillamo R et al. Vehicle engines produce 452 nanoparticles even when not fuelled. Environ. Sci. Technol. 2014;48:2043-2050.

453 [14] Filippo A, Maricq M. Diesel nucleation mode particles: Semivolatile or solid? Environ. Sci. Technol. 2008; $454 \quad 42: 7957-7962$.

455 [15] Kittelson DB, Watts WF, Johnson JP, Thorne C, Higham C, Payne J et al. Effect of fuel and lube oil sulfur 456 on the performance of a diesel exhaust gas continuously regenerating trap. Environ. Sci. Technol. $457 \quad 2008 ; 42: 9276-9282$. 
458

459

460

461

462

463

464

465

466

467

468

469

470

471

472

473

474

475

476

477

478

479

480

481

482

483

484

485

486

487

488

[16] Rönkkö T, Lähde T, Heikkilä J, Pirjola L, Bauschke U, Arnold F et al. Effect of gaseous sulphuric acid on diesel exhaust nanoparticle formation and characteristics. Environ. Sci. Technol. 2013; 47:11882-11889.

[17] Vaaraslahti K, Virtanen A, Ristimäki J, Keskinen J. Nucleation mode formation in heady-duty diesel exhaust with and without a particulate filter. Environ. Sci. Technol. 2004;38:4884-4890.

[18] Lähde T, Rönkkö T, Virtanen A. Schuck TJ, Pirjola L, Hämeri K et al. Heavy duty diesel engine exhaust aerosol particle and ion measurements.Environ. Sci. Technol. 2009;43:163-168.

[19] Pirjola L, Dittrich A, Niemi JV, Saarikoski S, Timonen H, Kuuluvainen H et al. Physical and chemical characterization of real-world particle number and mass emissions from city buses in Finland. Environ. Sci. Technol. 2016;50:294-304.

[20] Maricq M, Chase R, Xu N, Laing P. The effects of the catalytic converter and fuel sulphur level on motor vehicle particulate matter emissions: Light duty diesel vehicles. Environ. Sci. Technol. 2002;36: 283-289.

[21] Vaaraslahti K, Keskinen J, Giechaskiel B, Solla A, Murtonen T, Vesala H. Effect of lubricant on the formation of heavy-duty diesel exhaust nanoparticles. Environ. Sci. Technol. 2005;39:8497-8504.

[22] Pirjola L, Karjalainen P, Heikkilä J, Saari S, Tzamkiozis T, Ntziachristos L et al. Effects of fresh lubricant oil on particle emissions emitted by a modern GDI passenger car. Environ. Sci. Technol. 2015;49:3644-3652.

[23] Rönkkö T, Virtanen A, Vaaraslahti K, Keskinen J, Pirjola L, Lappi M. Effect of dilution conditions and driving parameters on nucleation mode particles in diesel exhaust: laboratory and on-road study. Atmos. Environ. 2006;40:2893-2901.

[24] Arnold F, Pirjola L, Aufmhoff H, Schuck T, Lähde T, Hämeri K. First gaseous sulfuric acid measurements in automobile exhaust: Implications for volatile nanoparticle formation. Atmos. Environ. 2006;40:7097-7105.

[25] Arnold F, Pirjola L, Rönkkö T, Reichl U, Schlager H, Lähde T et al.. First on-line measurements of sulfuric acid gas in modern heavy duty diesel engine exhaust: Implications for nanoparticle formation. Environ. Sci. Technol. 2012;46:11227-11234.

[26] Shi J, Harrison R. Investigation of ultrafine particle formation during diesel exhaust dilution, Environ. Sci. Technol. 1999;33: 3730-3736.

[27] Schneider J, Hock N, Weimer S, Bormann S, Kirchner U, Vogt R et al. Nucleation particles in diesel exhaust:

Composition inferred from in situ mass spectrometer analysis. Environ. Sci. Technol. 2005;39:6153-6161.

[28] Khalek IA, Spears M, Charmley W. Particle size distribution from heady-duty diesel engine: Steady-state and transient emission measurement using two dilution systems and two fuels. SAE Tech. Pap. Ser. 2003; 2003-0285. [29] van Helden R, Verbeek R, Willems F, van der Welle R. Optimization of Urea SCR deNOx Systems for HD Diesel Engines. SAE Technical Paper 2004-01-0154, 2004. 
[30] Emberger P, Hebecker D, Pickel P, Remmele E, Thuneke K. Emission behavior of vegetable oil fuel compatible tractors fuelled with different pure vegetable oils. Fuel 2016;167:257-270.

[31] Müllerova D, Landis M, Schiess I, Jablonicky J, Pristavke M. Operating parameters and emission evaluation of tractors running on diesel oil and biofuel. Res. Agr. Eng 2011;57:535-542.

[32] He C, Ge Y, Tan J, You K, Han Z, Wang J. Characteristics of polycyclic aromatic hydrocarbons emissions of diesel engine fueled with biodiesel and diesel. Fuel 2010;89:2040-2046.

[33] Lee W-J, Liu Y-C, Mwangi FK, Chen W-H, Lin S-L, Fukushima Y et al. Assessment of energy performance and air pollutant emissions in a diesel engine generator fueled with water-containing ethanol-biodiesel-diesel blend of fuels. Energy 2011;36:5591-5599.

[34] Tang S, LaDuke G, Chien W, Frank BP. Impacts of biodiesel blends on $\mathrm{PM}_{2.5}$, particle number and size distribution, and elemental/organic carbon from nonroad diesel generators. Fuel 2016;172:11-19..

[35] Chung A, Lall AA, Paulson SE. Particulate emissions by a small non-road diesel engine: Biodiesel and diesel characterization and mass measurements using the extended idealized aggregates theory. Atmos. Environ. 2008;42:2129-2140.

[36] Zhang Z-H, Balasubramanian R. Influence of butanol-diesel blends on particulate emissions of a non-road diesel engine. Fuel 2014;118:130-136.

[37] Heikkilä J, Virtanen A, Rönkkö T, Keskinen J, Aakko-Saksa P, Murtonen T. Nanoparticle Emissions from a Heavy-Duty Engine Running on Alternative Diesel Fuels. Environ. Sci. Technol. 2009;43: 9501-9506.

[38] Kuronen M, Mikkonen S, Aakko P, Murtonen T. Hydrotreated vegetable oil as fuel for heavy duty diesel engines. SAE Technical Paper Series 2007;2007-01-4031.

[39] Aatola H, Larmi M, Sarjovaara T, Mikkonen S. Hydrotreated vegetable oil (HVO) as a renewable diesel fuel: Trade-off between $\mathrm{NO}_{x}$, particulate emission, and fuel consumption of a heavy duty engine. SAE Int. J. Engines $2008 ; 1: 1251-1262$.

[40] Happonen M, Heikkilä J, Murtonen T, Lehto K, Sarjovaara T, Larmi M, et al. Reductions in particle and NOx emissions by diesel engine parameter adjustments with HVO fuel. Environ Sci Technol 2012;46:6198-204.

[41] Pirjola L, Parviainen H, Hussein T, Valli A, Hämeri K, Aalto P et al. "Sniffer" - a novel tool for chasing vehicles and measuring traffic pollutants. Atmos. Environ. 2004;38:3625-3635.

[42] Mirme A. Electrical aerosol spectrometry, Ph.D. thesis, University of Tartu, 1994.

[43] Johnson T, Caldow R, Pocher A, Mirme A, Kittelson D. A New Electrical Mobility Particle Size Spectrometer for Engine Exhaust Particle Measurements. SAE Tech. Pap. Ser. 2004;2004-1341.

[44] Keskinen J, Pietarinen K, Lehtimäki M. Electrical low pressure impactor. J. Aerosol Sci. 1992;23:353-360. 
[45] Marjamäki M, Ntziachristos L, Virtanen A, Ristimäki J, Keskinen J, Moisio M et al. Electrical filter stage for the ELPI. SAE Tech. Pap. Ser. 2002;2002-01-0055.

[46] Yli-Ojanperä J, Kannosto J, Marjamäki M, Keskinen J. Improving the nanoparticle resolution of the ELPI. Aerosol Air Qual. Res. 2010;10:360-366.

524 [47] Rönkkö T, Arffman A, Karjalainen P, Lähde T, Heikkilä J, Pirjola L et al. Diesel Exhaust Nanoparticle

525 Volatility Studies by a New Thermodenuder with Low Solid Nanoparticle Losses. In Abstracts in the 15th ETH 526 Conference on Combustion Generated Nanoparticles, 26-29 June, Zürich, Switzerland, 2011.

527 [48] Heikkilä J, Rönkkö T, Lähde T, Lemmetty M, Arffman A, Virtanen A et al. Effect of open channel filter on 528 particle emissions of modern diesel engine. J. Air Waste Manage. Assoc. 2009; 59:1148-1154.

529 [49] Ntziachristos L, Giechaskiel B, Pistikopoulos P, Samaras Z, Mathis U, Mohr M et al. Performance valuation 530 of a novel sampling and measurement system for exhaust particle characterization. SAE Tech. Paper Series, $531 \quad 2004 ; 2004-01-1439$.

532 [50] Keskinen J, Rönkkö T. Can Real-World Diesel Exhaust Particle Size Distribution be Reproduced in the 533 Laboratory? A Critical Review. J. Air Waste Manage. Assoc. 2010;60:1245-1255.

534 [51] Saari S, Karjalainen P, Ntziachristos L, Pirjola L, Matilainen P, Keskinen J et al. Exhaust particle and NOx emission performance of an SCR heavy duty truck operating in real-world conditions. Atmos. Environ. 201;126:136-144.

[52] Huss A, Maas H, Hass H. Well-to-wheels analysis of future automotive fuels and powertrains in the European context. Tank-To-Wheels (TTW) Report Version 4.0, July 2013. http://iet.jrc.ec.europa.eu/about-jec.

539 [53] Karjalainen P, Rönkkö T, Pirjola L, Heikkilä J, Happonen M, Arnold F,Ntziachristos L et al. Sulfur driven 540 nucleation mode formation in diesel exhaust under transient driving conditions. Environ. Sci. Technol. $541 \quad 2014 ; 48: 2336-2343$.

542 [54] Giakoumis EG, Rakopoulos DC, Rakopoulos CD. Combustion noise radiation during dynamic diesel engine 543 operation including effects of various biofuels blends: A review. Renew. Sust. Energy Rev. 2016;54;1099-1113.

544 [55] Rakopoulos DC, Rakopoulos CD, Giakoumis EG. Impact of properties of vegetable oil, bio-diesel, ethanol 545 and n-butanol on the combustion and emissions of turbocharged HDDI diesel engine operating under steady and 546 transient conditions. Fuel 2015;156;1-19.

547 [56] Rakopoulos DC, Rakopoulos CD, Kyritsis DC. Butanol or DEE blends with either straight vegetable oil or 548 biodiesel excluding fossil fuel: Comparative effects on diesel engine combustion attributes, cyclic 549 variability and regulated emissions trade-off. Energy 2016;115;314-325. 
550 [57] Giechaskiel B, Dilara P, Sandbach E, Andersson J. Particle measurement programme (PMP) light-duty inter551 laboratory exercise: comparison of different particle number measurement systems. Meas. Sci. Technol. $552 \quad 2008 ; 19 ; 095401$.

553 [58] Maricq MM, Podsiadlik DH, Chase RE. Size Distributions of Motor Vehicle Exhaust PM: A Comparison 554 Between ELPI and SMPS Measurements. Aerosol Science and Technology 2000;33;239-260.

555 [59] Nousiainen P, Niemi S, Rönkkö T, Karjalainen P, Keskinen J, Kuuluvainen H, Pirjola L, Saveljeff H. Effect 556 of Injection Parameters on Exhaust Gaseous and Nucleation Mode Particle Emissions of a Tier 4i Nonroad Diesel 557 Engine. SAE International 2013; 2013-01-2575.

558

559

560 


\section{Appendix A. Supplementary material}

Table S1. Properties of studied diesel (EN590) and HVO (NEXBTL) fuels from fuel analysis.

\begin{tabular}{lrrr} 
& & EN590 & NEXBTL \\
Density & $\mathrm{kg} / \mathrm{m} 3$ & 821.5 & 778.6 \\
Viscosity at $40{ }^{\circ} \mathrm{C}$ & $\mathrm{mm} 2 / \mathrm{s}$ & & 2.831 \\
Cetane number & & 53 & 77 \\
Net heat of combustion & $\mathrm{MJ} / \mathrm{kg}$ & 43.206 & 43.956 \\
Sulphur content & $\mathrm{mg} / \mathrm{kg}$ & 5.8 & $<1$ \\
Water coloumetric & $\mathrm{mg} / \mathrm{kg}$ & 23 & 17 \\
Carbon & $\mathrm{wt}-\%$ & 85.2 & 84.5 \\
Hydrogen & $\mathrm{wt}-\%$ & 13.7 & 15.1 \\
Ash, 775 ${ }^{\circ} \mathrm{C}$ & $\mathrm{wt}-\%$ & $<0.001$ & $<0.001$ \\
Monoaromatics & $\mathrm{wt}-\%$ & 17.8 & 0.2 \\
Diaromatics & $\mathrm{wt}-\%$ & 1.6 & $<0.1$ \\
Trit-aromatics & $\mathrm{wt}-\%$ & 1.7 & $<0.1$ \\
n-paraffins, C10-C20 & ${ }^{\circ} \mathrm{C}$ & & 5.91 \\
n-paraffins, C6-C36 & ${ }^{\circ} \mathrm{C}$ & 316.1 & 293.9 \\
Distillation 5 vol-\% & ${ }^{\circ} \mathrm{C}$ & 186.9 & 237.8 \\
Distillation 50 vol-\% & & 235.4 & 277.4 \\
Distillation 90 vol-\% & & & 6.4 \\
Distillation 95 vol-\% & & & 289.1 \\
& & & \\
\hline
\end{tabular}

Table S2. Analyzers for raw exhaust measurements.

\begin{tabular}{|c|c|c|c|}
\hline Substance & Manufacturer & Model & Measurement principle \\
\hline $\mathrm{O}_{2}$ & Servomex & Xentra 4900 & Paramagnetic cell \\
\hline $\mathrm{CO}$ & Servomex & Xentra 4900 & NDIR \\
\hline $\mathrm{CO}_{2}$ & Servomex & Xentra 4900 & NDIR \\
\hline $\mathrm{HC}$ & CAI & 300-HFID & FID \\
\hline $\mathrm{NO}, \mathrm{NO}_{\mathrm{x}}$ & Eco Physics & CLD $700 \mathrm{EL} \mathrm{ht}$ & Chemiluminescence \\
\hline NOx sensor & Continental & UNINOx 6614J & $\begin{array}{ll}\text { Amperometric } & \text { double } \\
\text { chamber principle } & \end{array}$ \\
\hline Smoke & AVL & $415 \mathrm{~S}$ & Filter paper method \\
\hline $\mathrm{PM}$ & Pegasor & M-sensor & $\begin{array}{l}\text { Particle are charged and } \\
\text { electrically detected }\end{array}$ \\
\hline
\end{tabular}


a)

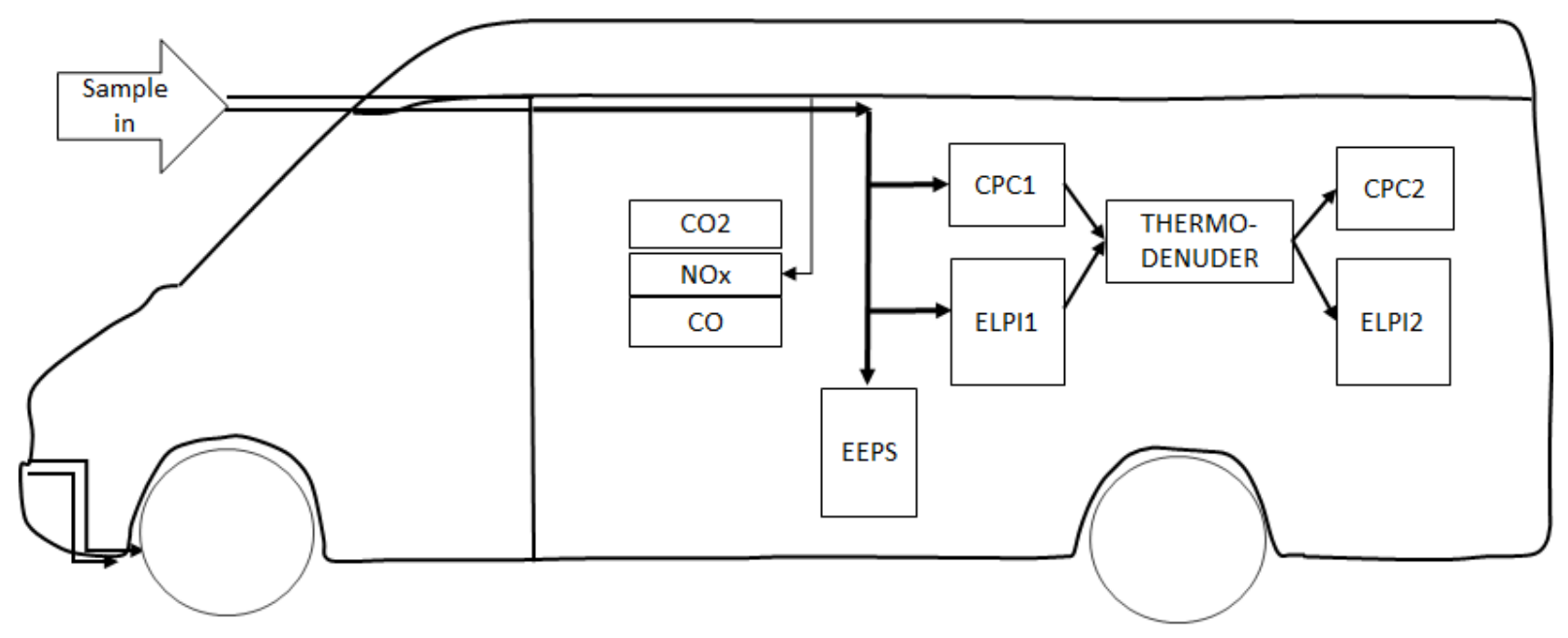

b)

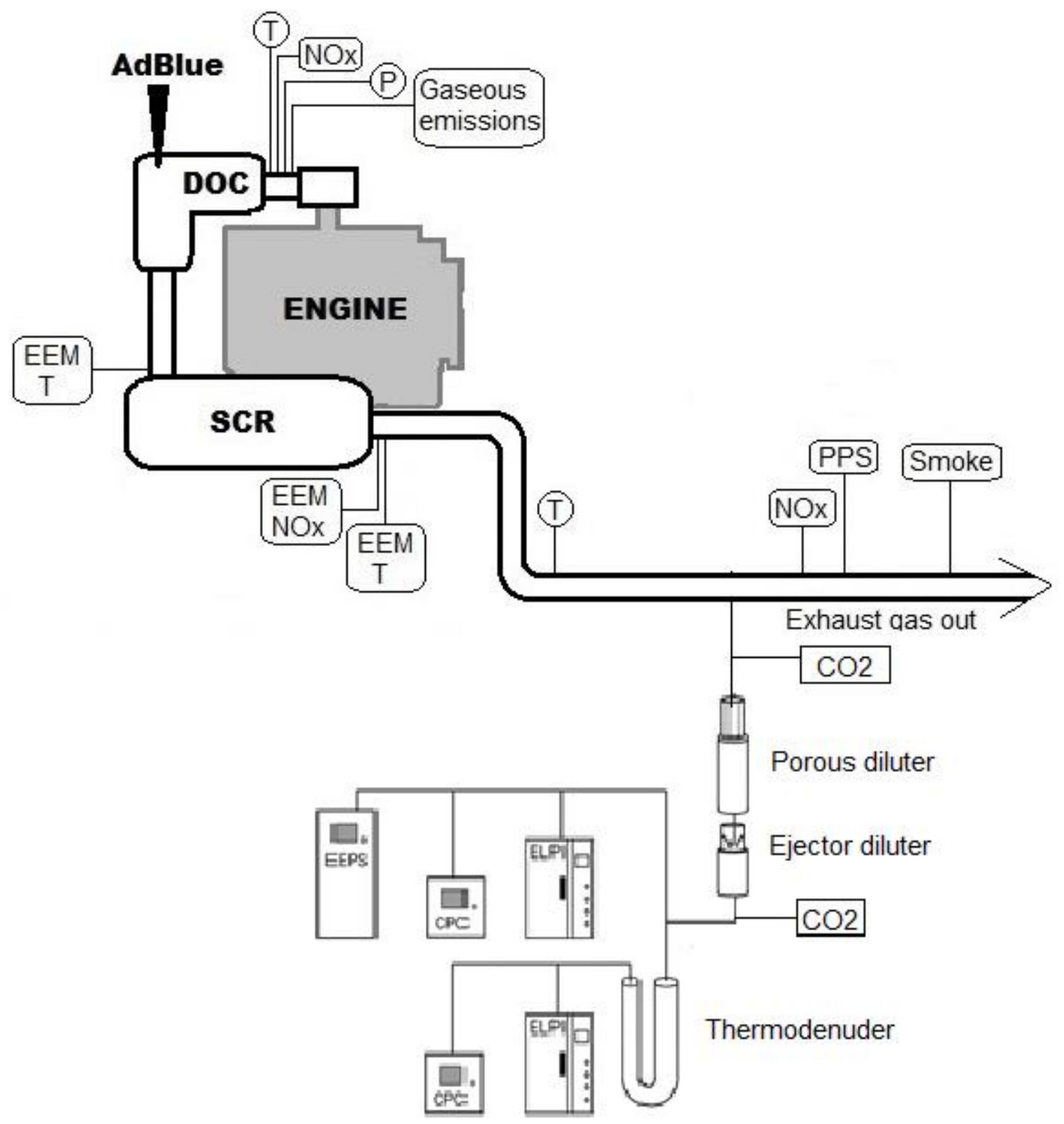

Figure S1. Measurement set up for chasing (a) and for the dynamometer (b). 
a)

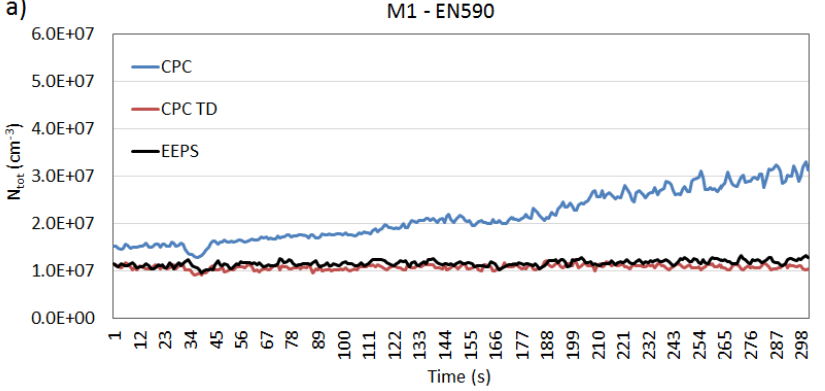

c)

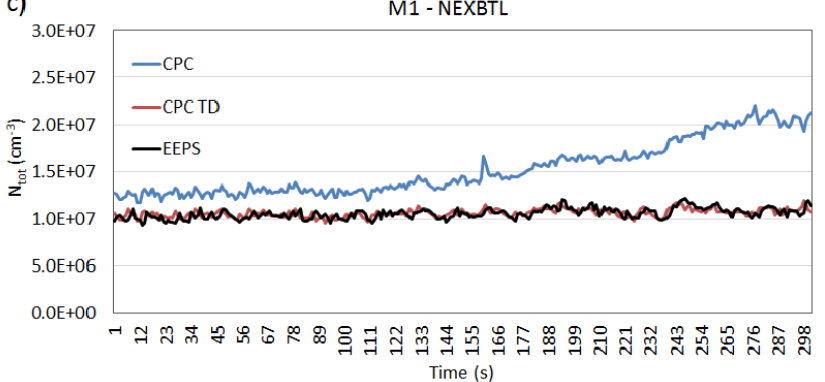

b)

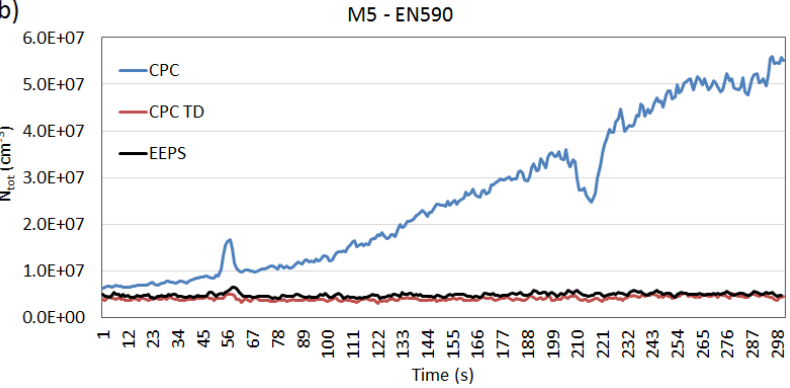

d)

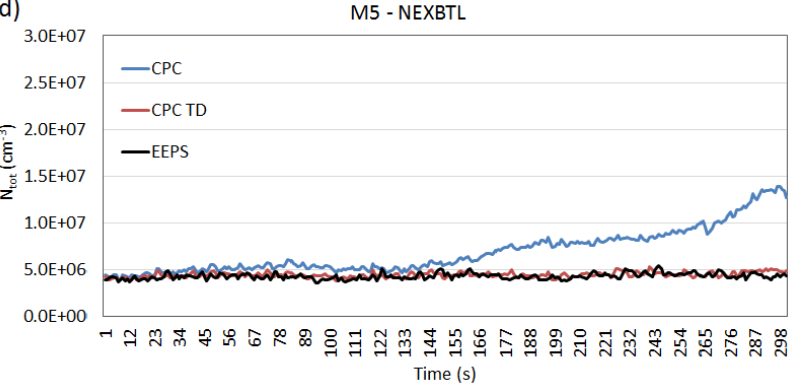

Figure S4. Time series of particle number concentrations at steady modes M1 (2200 rpm, 100\% engine load) and M5 (1500 rpm, $100 \%$ engine load) for both fuels. Measurements were carried out with the CPC and EEPS before the thermodenuder (TD) and with the other CPC after the TD. Concentrations were calculated to raw exhaust. 